\title{
Eksistensi Payung Dalam Kebudayaan Minangkabau Di Era Globalisasi
}

\author{
Yulinis
}

Fakultas Seni Pertunjukan, Institut Seni Indonesia Denpasar

yulinis.1964@gmail.com

Payung tidak hanya dipergunakan untuk hal-hal praktis dalam kehidupan sehari-hari seperti melindungi diri dari kehujanan atau kepanasan. Akan tetapi payung telah menjadi simbol dalam kebudayaan terutama di Minangkabau. Eksistensi payung dalam kebudayaan Minangkabau tentu saja mengalami perkembangan. Payung yang sebelumnya digunakan untuk hal yang praktis, sekarang sudah menjadi simbolis. Perubahan tersebut merupakan sikap terhadap kondisi masyarakat yang telah dipengaruhi oleh globalisasi. Globalisasi membawa penyebaran budaya pluralistik dengan berbagai ideologi yang terkandung di dalamnya yang sulit dihindarkan. Dalam hal ini globalisasi, tidak hanya dalam bidang-bidang tertentu, seperti teknologi, tetapi juga bidangbidang lainnya sesuai dengan karakter dan makna global itu sendiri. Globalisasi menimbulkan perubahan terhadap sebuah benda seperti payung yang sudah lama melekat dalam diri manusia tradisional. Pengaruh globalisasi menjadikan payung bersifat universal. Payung di Minangkabau telah difungsikan dalam upacara ritual pengangkatan penghulu yang dimaknai sebagai pelindung dari perilaku yang tidak baik. Payung juga menjadi simbol bagi perempuan Minangkabau. Perempuan diibaratkan sebagai payung panji ke Medinah yang bermakna sebagai jalan menuju surga dalam agama Islam. Payung yang dilekatkan kepada perempuan juga bermakna sebagai pemimpin, terutama pemimpin dalam keluarga, pemimpin bagi anak-anaknya di rumah. Payung juga digunakan dalam tari di Minangkabau. Tari payung tercipta sebagai penggambaran cinta dan kasih sayang antara laki-laki dan perempuan. Begitu juga dalam upacara perkawinan, payung menjadi simbol menyatukan dua anak manusia dalam sebuah keluarga.

Kata kunci: payung, eksistensi, globalisasi, Budaya, Minangkabau

\section{The Existence Of Umbrella In Minangkabau Culture In The Globalization Era}

Umbrella is not only used for practical things in everyday life such as protecting from rain or heat. However, the umbrella has become a symbol of culture, especially in Minangkabau. The existence of umbrellas in Minangkabau culture has grown up. Umbrella, which was previously used for practical purposes, has now become symbolic. The change is an attitude towards the condition of the community that has been influenced by globalization. Globalization brings the spread of pluralistic cultures with various ideologies in it that are difficult to avoid. In this case globalization is not only in certain fields, such as technology, but also other fields in accordance with the character and the meaning of global itself. Globalization leads to changes in an object such as an umbrella that has been inherent in traditional human beings for a long period of time. The influence of globalization makes umbrellas universal. Umbrella in Minangkabau has been functioned in the ritual ceremony of the appointment of the penghulu ( prince) which is interpreted as a protector of bad behavior. Umbrella is also a symbol for Minangkabau women. Women are likened to a banner umbrella to Medina which means a road to heaven in Islam. Umbrellas attached to women also mean as leaders, especially leaders in the family, leaders for their children at home. Umbrella is also used in dance in Minangkabau. The dance of umbrella was created as a description of love and affection between men and women. Likewise in wedding ceremonies, the umbrella becomes a symbol of uniting two people in a family.

Keywords: umbrella, existence, globalization, culture, Minangkabau

Proses Review : 1 - 18 April 2019, Dinyatakan Lolos: 22 April 2019 


\section{PENDAHULUAN}

Payung merupakan perlengkapan sehari-hari yang fungsi utamanya adalah melindungi diri dari hujan atau terik panas matahari. Fungsi ini kemudian dikembangkan menjadi fungsi simbolis di mana kata "melindungi" bisa dimaknai secara filosofis. Dari fungsi awal tersebut, payung kemudian digunakan untuk kebutuhan kebudayaan seperti pengakatan pemimpin, perkawinan, simbol perempuan dan sebagainya. Hal ini merupakan perubahan fungsi budaya secara global. Seperti yang dikatakan Haviland (1988:251), bahwa kebudayaan pada suatu waktu akan berubah. Setidaknya ada dua hal yang menjadi penyebab terjadinya perubahan kebudayaan. Pertama adalah terjadinya perubahan lingkungan yang dapat menuntut perubahan kebudayaan yang bersifat adaptif. Kedua terjadinya kontak dengan bangsa lain yang mungkin menyebabkan diterimanya kebudayaan asing sehingga terjadilah perubahan dalam nilai-nilai dan tata kelakukan yang ada. Kemampuan berubah merupakan sifat yang penting dalam kebudayaan manusia.

Kondisi kebudayaan dalam era globalisasi sekarang sangat bervariasi, ada yang berkembang baik dan ada pula yang mengalami kemunduran. Kemunduran ini disebabkan semakin tajamnya persaingan antar budaya. Hal ini bisa dilihat dari eksistensi budaya itu di tengah-tengah masyarakat. Salah satu kebudayaan yang berkembang hingga kini adalah simbolisasi payung. Secara historis payung erat kaitannya dengan pertumbuhan dan perkembangan kebudayaan Minangkabau terutama berhubungan dengan ritual adat dan tradisi di tengah masyarakat.

Dalam mengikuti arus globalisasi, payung harus mampu beradaptasi dan mengambil idiom-idiom kekinian, agar kebudayaan ini tidak musnah dan habis ditelan zaman. Payung sebagai symbol budaya bisa bertahan sampai hari ini karena memiliki mekanisme yang memungkinkan perubahan-perubahan itu terjadi, sehingga pada satu pihak tatanan atau stabilitas tidak terguncang tapi pada pihak lain perubahan atau pembaharuan terjadi. Perubahan dan pembaharuan yang terjadi pada payung dengan demikian akan dilihat juga sebagai bagian dari keselarasan dalam tatanan yang ada. Perubahan dan pembaharuan dengan demikian pula tidak hanya suatu proses yang terjadi karena pengaruh dari luar akan tetapi juga dari dalam.

\section{METODE}

Tulisan ini menggunakan metode kualitatif yang mengkaji eksistensi payung dalam kebudayaan Minangkabau di era globalisasi melalui analisis fenomena dan wacana. Metode kualitatif dapat digunakan untuk menganalisis berbagai masalah ilmu sosial humaniora, seperti demokrasi, ras, gender, kelas, negara bangsa, globalisasi, kebebasan, dan masalah-masalah kemasyarakatan (Ratna, 2010:93).
Metode yang digunakan dalam penulisan ini disesuikan dengan kajian budaya seperti yang dikatakan Mariyah (2011:4-5) bahwa secara epistemologis, kajian budaya juga memiliki cara atau pendekatan tersendiri yang membedakannya dengan bidang keilmuan lainnya. Namun, pengertian epistemologi yang diterapkan dalam kajian budaya tidak sama dengan 'pendekatan fungsi' yang berarti berguna. Pengertian epistemologis merupakan cara atau teknik memperoleh ilmu pengetahuan, sedangkan pengertian fungsi menyangkut bagaimana keterhubungan berlangsung.

Pendekatan yang digunakan adalah pendekatan eklektisisme. Eklektik menurut Ratna (2010:461) adalah penggunaan sejumlah teori, sejumlah metode, sejumlah teknik secara bersama-sama secara 'mana suka'. Semula berarti memilih ajaran yang terbaik, kemudian berarti penggabungan gaya dalam arsitektur dan karya seni yang lain. Dalam hal ini, setiap fenomena yang kompleks selayaknya dianalisis menggunakan teori secara eklektik untuk mendapatkan hasil penelitian yang valid.

Eklektisisme (Eclecticism) adalah suatu cara pandang yang menyatakan bahwa berbagai strategi teoretis harus digunakan secara kombinasi agar diperoleh penjelasan yang dapat diterima (Sanderson, 1993:618). Pendekatan secara eklektik digunakan dalam ilmu-ilmu sosial, humaniora, dan kajian budaya karena pada teori-teori tertentu memiliki kekuatan dan kelemahan sehingga pengombinasian beberapa teori lebih valid dalam konteks yang utuh.

\section{HASIL DAN PEMBAHASAN}

Payung Sebagai Ritual Pengangkatan Pimpinan (Penghulu)

Penghulu merupakan salah satu unsur pimpinan di Minangkabau. Unsur pimpinan dalam nagari yang mengawal kehidupan terdiri atas penghulu, alim ulama, dan cerdik pandai yang disebut dengan tungku tigo sajarangan atau tali tigo sapilin. Ketiga unsur pimpinan ini adalah orang yang didahulukan selangkah dan ditinggikan seranting, artinya pemimpin tidak terlalu berjarak dengan orang atau masyarakat yang dipimpinnya. Penghulu adalah seorang laki-laki yang dituakan di dalam sebuah suku di Minangkabau. Penghulu atau niniak mamak dalam kehidupan sehari-hari disebut dengan panggilan "datuak". Masing-masing penghulu merupakan wakil dari suku-suku yang ada, dan kumpulan penghulu akan diketuai oleh satu penghulu pucuk yang dipilih berdasarkan musyawarah di antara sesama penghulu tersebut.

Alim ulama adalah pemimpin masyarakat Minangkabau dalam urusan agama. Keberadaannya dalam masyarakat sangat dibutuhkan untuk mengatur etika masyarakat berdasarkan agama Islam. Alim ulama ditunjuk berdasarkan pengetahuannya terhadap agama Islam dan diberi gelar "tuanku". Cerdik pandai adalah orang yang memiliki kelu- 
asan pemikiran yang dapat mencari jalan keluar dari setiap masalah yang di hadapi masyarakat, memiliki ilmu pengetahuan umum yang luas, anggota masyarakat yang dapat mengikuti perkembangan zaman. Keluasan pemikiran dan kemampuannya diharapkan dapat mengantisipasi segala yang terjadi ditengah masyarakat nagari. Ketiga unsur pimpinan inilah yang mengatur segalanya dalam nagari termasuk urusan pamenan anak nagari.

Salah satu ritual pengangkatan penghulu di Minangkabau adalah memakai payung sebagai lambang kebesaran pimpinan. Maknanya adalah bagaimana penghulu bisa memayungi seluruh anak kemenakannya. Hal ini sama dengan pohon besar di tengah kampung yang bisa melindungi seluruh masyarakat. Ini berhubungan dengan alam sebagai guru bagi masyarakat. Hubungan antara alam dan manusia adalah sebuah keharusan yang tidak dapat ditolak, karena hubungan tersebut memiliki nilai-nilai sakral yang sangat tinggi. Hal ini diungkapkan dalam personifikasi mistik kekuatan alam, yakni kepercayaan pada makhluk gaib, kepercayaan pada dewa pencipta, atau dengan mengkonseptualisasikan hubungan antara berbagai kelompok sosial sebagai hubungan antara binatang-binatang, burung-burung, atau kekuatan-kekuatan alam (Keesing, 1992: 131). Upacara adat seperti pengangkatan penghulu erat kaitannya dengan ritual-ritual keagamaan atau disebut juga dengan ritus. Ritus adalah alat manusia religius untuk melakukan perubahan. Ia juga dikatakan sebagai simbolis agama, atau ritual itu merupakan "agama dan tindakan" (Ghazali, 2011 : 50). Seorang penghulu tidak bisa mengambil keputusan dengan kehendak sendiri. Semua keputusan adalah hasil dari mufakat dan bersama-sama untuk mencapai tujuan. Individu-individu tidak bisa melepaskan diri dari tanggungjawab terhadap sesuatu yang terjadi dalam masyarakat kampung dan nagari. Keturunan di atur menurut garis ibu. Individu akan melihat dirinya sebagai turunan dari ibunya dan nenek perempuannya ke atas. Garis keturunan ini meneruskan harta warisan dari keluarga ibunya, sehingga kalau dia meninggal harta itu akan kembali kepada keturunan menurut garis ibunya. Seorang penghulu harus berusaha jangan sampai harta pusaka anak-kemenakan dan kaum tergadai tidak menurut semestinya. Penghulu harus menerapkan pepatah adat barek samo dipikua, ringan samo dijinjiang (berat sama-sama dipikul, ringan sama-sama dijinjing).

Ritual pengangkatan penghulu juga dikaitkan dengan ritual keagamaan yang dilakukan oleh masyarakat berdasarkan kepercayaan yang dianut oleh masyarakatnya. Kepercayaan seperti inilah yang mendorong manusia untuk melakukan berbagai perbuatan atau tindakan yang bertujuan mencari hubungan dengan dunia gaib penguasa alam melalui ritual-ritual, baik ritual keagamaan (religious ceremonies) maupun ritual-ritual adat lainnya yang dirasakan oleh masyarakat sebagai saat-saat genting, yang bisa membawa bahaya gaib, kesengsaraan dan penyakit kepada manusia maupun tanaman (Koentjaraningrat, 1985:
243-246). Ritual pengangkatan penghulu bertujuan agar penghulu bisa menjadi pemimpin yang amanah dan dapat dipercaya oleh masyarakatnya.

Payung dalam upacara ritual pengangkatan penghulu juga dimaknai sebagai pelindung dari perilaku yang tidak baik dari seorang pimpinan. Kebudayaan Minangkabau mempunyai pepatah yaitu nan kuriak kundi nan merah sago, nan baiak budi nan endah baso (yang kurik kundi yang merah saga, yang baik budi yang indah bahasa). Jadi bahasa merupakan pengungkap dari keindahan baik bahasa dalam pengertian 'kata' maupun bahasa dalam pengertian perilaku atau tatakrama.

Pelaksanaan upacara adat pengangkatan pengulu maupun ritual keagamaan yang didasari atas adanya kekuatan gaib masih tetap dilakukan oleh sebagian kelompok masyarakat di Indonesia, baik berupa ritual kematian, ritual syukuran atau slametan, ritual tolak bala, ritual ruwatan, dan lain sebagainya (Marzuki, 2015:1). Ritual-ritual ini telah menjadi tradisi dan menjadi bagian dari kehidupan sehari-hari sebagian besar masyarakat karena telah diwariskan secara turun-temurun oleh nenek moyang mereka kepada generasi berikutnya. Penghulu ketika meninggal juga dipayungi menuju kuburannya.

Sementara itu, menurut Harton dan Hunt (1987: 327) pranata agama memiliki fungsi manifes dan fungsi laten. Fungsi manifes (nyata) agama berkaitan dengan segi-segi doktrin, ritual, dan aturan perilaku dalam agama. Tujuan dan fungsi agama adalah untuk membujuk manusia agar melaksanakan ritus agama, bersama-sama menerapkan ajaran agama, dan menjalankan kegiatan yang diperkenankan agama. Sedangkan fungsi laten agama, antara lain menawarkan kehangatan bergaul, meningkatkan mobilitas sosial, mendorong terciptanya beberapa bentuk stratifikasi sosial, dan mengembangkan seperangkat nilai ekonomi.

Kondisi sekarang, memang tidak seideal yang disebutkan di atas. Pengaruh rantau, globalisasi, dan teknologi informasi telah merubah tatanan yang ideal tersebut. Sekolah-sekolah formal telah mengajarkan mereka tentang semua unsur yang selama ini diperankan oleh penghulu. Wisran Hadi (2007: 1) mengatakan bahwa globalisasi dengan berbagai dampak negatifnya telah dianggap sebagai bentuk penjajahan bentuk baru atau imperialisme modern. Bangsa-bangsa yang maju dan kuat ekonominya tidak perlu menjajah sebuah negara atau bangsa lain dengan kekuatan senjata, tetapi cukup menciptakan suatu ketergantungan. Negara-negara berkembang harus tergantung pada negara-negara yang kuat dalam berbagai sektor, terutama dalam sektor ekonomi, politik dan keamanan. Bahkan pemilihan seorang presiden dari negara berkembang dapat dicampuri oleh kekuatan negara maju dan kuat itu. Invasi yang dilakukan Amerika terhadap Iraq dan Afganistan adalah salah bentuk pengaplikasian isyu globalisasi dari negara kuat kepada negara yang lemah. 
Laki-laki Minangkabau awalnya belajar di surau untuk menempa perilakunya, kemudian juga belajar tentang dunia di rantau. Setelah merantau, idealnya laki-laki Minangkabau akan kembali ke kampung halaman menjadi ninik mamak atau penghulu agar bisa mengajarkan kepada generasi muda tentang perjalanan manusia Minangkabau yang kompleks. Setelah tua ia kembali ke surau agar pengetahuan tersebut bisa diturunkan kepada generasi muda. siklus perjalanan seorang Minang mulai dari; rumah gadang, terus ke surau, selanjutnya ke lapau dan galanggang, kawin dan merantau, jadi mamak atau penghulu, lalu kembali ke surau, adalah sebuah perjalanan individu Minang tradisi dalam penyempurnaan kehidupannya. Dari siklus ini terlihat, bahwa surau benar-benar sebuah sarana yang paling urgen dan efektif bagi kehidupan seorang individu Minang.

\section{Payung dan Perempuan Minangkabau}

Dalam pepatah orang Minangkabau berbunyi perempuan itu adalah payuang panji ka Madinah (payung panji ke Medinah). Menurut Thaib (2010: 4), perempuan Minangkabau secara ideal harus berperan dan berfungsi sebagai berikut; (1) Puncak dan basis dari sistem kekeluargaan yang disebut matrilineal; (2) Pemimpin masyarakatnya; (3) Pemeran utama dalam kehidupan sosial budaya; (4) Figur yang mulia dan dimuliakan; dan (5) Tokoh, pejuang, pendidik, jurnalis, politisi, pengusaha dan berbagai bidang dan aktifitas lainnya. Kelima peran dan fungsi perempuan Minangkabau tersebut di atas, didasarkan pada pengakuan adat Minangkabau itu sendiri terhadap hakekat perempuan (Thaib 2008: 4-5). Perempuan Minangkabau dalam ungkapan budayanya adalah induak bareh, urang rumah, mande, bundo kanduang, limpapeh rumah nan gadang, amban puruik, aluang bunian, payuang panji ka Madinah, unduang-unduang ka sarugo, (Ibu beras, orang rumah, ibu, bunda kadung, perhiasan rumah besar, bendaharawan, tempat informasi, payung panji ke Madinah, undungundung ke surga). Di samping itu, posisi perempuan Minangkabau adalah pelanjut keturunan, perekat, sitawa sidingin (menawarkan mendinginkan).

Perempuan diibaratkan sebagai payung panji ke Medinah yang bermakna sebagai jalan menuju surga dalam agama Islam. Ini juga berkaitan dengan pepatah bahwa surga terletak di bawah telapak kaki ibu (perempuan). Salah satu pemimpin di Minangkabau adalah Bundo Kanduang namun ia hanya menjadi pengontrol kekuasaan. Bundo Kanduang adalah pemilik negeri yang menjadi legislatif dalam kekuasaan. Perempuan tetap diposisikan dalam kaum sebagai sesuatu yang mulia dan steril, terbebas dari berbagai kemungkinan merusak diri atau citranya.

Payung yang dilekatkan kepada perempuan juga bermakna sebagai pemimpin, terutama pemimpin dalam keluarga, pemimpin bagi anak-anaknya di rumah. Perempuan Minangkabau dalam beberapa Kaba ditampilkan sebagai sosok yang bijaksana, jatmika, dan perkasa dalam berbagai bidang. Gambaran ideal tentang perempuan Minangkabau itu seolah-olah menjadi kenyataan dengan eksisnya para tokoh perempuan dalam sejarah Minangkabau seperti Rohana Kudus, Rahmah El-Yunusiah, Rasuna Said, Yang Dipertuan Gadih Puti Reno Sumpu, dan Siti Manggopoh. Mereka adalah tokoh-tokoh perempuan pekerja keras yang tangguh dalam mewujudkan cita-citanya.

Ketangguhan perempuan Minangkabau banyak digambarkan dalam cerita rakyat Minangkabau. Tambo, kaba, mitos, legenda dan sebagainya menjadi inspirasi untuk membicarakan sesuatu yang lebih universal tentang perempuan. Cerita Malin Kundang misalnya yang selalu aktual sebagai cerita yang mendidik anak agar tidak durhaka kepada orangtuanya (perempuan). Begitu juga dengan cerita Anggun Nan Tongga yang memperlihatkan kisah kesetiaan perempuan Minangkabau yang bernam Gondan Gandoriah. Hal ini merupakan realitas budaya yang memperlihatkan tingkat intelektual perempuan Minangkabau yang cukup tinggi. Hal ini bisa ilihat dalam tukang kaba di mana mereka dengan cerdas memberi isian-isian yang kadangkala tidak terduga sehingga cerita menjadi lebih menarik. Untuk itu, setiap cerita yang sama akan selalu enak untuk ditonton karena akan menghasilkan hal yang berbeda dari tontonan sebelumnya. Nilai dari cerita rakyat itu bisa berupa nilai pendidikan, moral, dan sosial budaya. Cerita rakyat tentang perempuan ini merupakan konsep seni tradisi di Minangkabau. Tukang kaba bisa mempermainkan cerita dan realitas kekinian sebagai bahan untuk menciptakan seni yang baik.

Berdasarkan mitos (cerita rakyat) Bundo Kanduang inilah, perempuan Minangkabau menduduki posisi penting dalam struktur kekuasaan. Dalam praktik kehidupan sehari-hari perempuan Minangkabau menjadi penguasa negeri yang ditunjukkan dengan posisinya sebagai pemilik rumah gadang. Dalam sistem matriarkhi, sesungguhnya perempuan Minangkabau diuntungkan. Meskipun kaum laki-laki Minangkabau adalah mamak yang berperan sebagai eksekutor, tetapi kaum perempuanlah yang sesungguhnya mempengaruhi pengambilan keputusan-keputusan itu.

Pada masa sekarang, posisi perempuan tidak seperti dalam cerita rakyat. Perempuan merupakan simbol manusia yang memberontak akibat eksistensi dirinya yang harus sejajar dengan laki-laki. Ajaran agama Islam mengharuskan perempuan menutup auratnya dan meletakan dirinya pada sesuatu yang pantas. Perempuan sekarang adalah perempuan yang tidak mau dijajah oleh laki-laki. Hal ini merupakan memanusiakan manusia yang sangat berarti dalam kehidupan ini. Sikap memperjuangkan keberadaan perempuan juga merupakan bagian dari perjuangan gender yang selama ini sangat gencar dilakukan oleh aktivis perempuan di Indonesia. 
Payung dalam diri perempuan Minangkabau juga berkaitan dengan nilai malu dan sopan santun. Akibatnya sebagai bentuk atribut budaya Islam hadir dalam pementasan ini termasuk cara berpakaian dan juga cara berperilaku. Keterlibatan kaum perempuan Minangkabau dalam pengambilan keputusan itu terjadi, karena berdasarkan garis keturunan dan harta pusaka, kaum perempuanlah yang lebih kompeten. Dalam hal ini dapat dikatakan, bahwa dalam sistem matriarkhat, posisi peran antara perempuan dan laki- laki adalah berimbang dan seimbang. Kaum perempuan Minangkabau bergerak dalam ranah moral sebagai pengontrol, pengawas sekaligus sebagai penetral kebijakkan. Sementara itu kaum laki- laki bergerak dalam ranah hukum.

Karakter perempuan yaitu sebagai tempat bertanya, mengadu, pemilik harta pusaka, dan sebagainya. Perempuan Minangkabau yang secara sadar dan ikhlas menjalani kehidupan sosialnya sebagai perempuan Minangkabau. Namun sekarang akibat tantangan zaman perempuan berubah karakternya menjadi perempuan yang memiliki keraguan terhadap kemampuan dan eksistensi dirinya. Perempuan Minangkabau hari ini (akibat globalisasi) tidak percaya diri pada kemampuannya. Perempuan Minangkabau saat ini merupakan perempuan yang menerapkan nilai-nilai baru secepatnya dalam kehidupan sosialnya tanpa lagi perlu mempertimbangkannya dengan nilai-nilai yang telah mereka jalani selama ini. Mereka merasa perlu sesegera mungkin menjadi modern atau disebut modern. Mereka didik anak-anak mereka untuk menjadi modern. Modern hanya sebatas tingkah laku tapi bukan dalam sikap hidup. Perempuan Minangkabau yang tidak lagi membiasakan memakai bahasa Minangkabau kepada anak-anaknya adalah gejala keinginan untuk menjadi modern itu tadi.

\section{Payung Sebagai Properti Seni Tari}

Minangkabau dalam dunia kesenian memiliki banyak bentuk dan jenis tari yang yang menghidupkan kebudayaan masyarakat. Selain Tari Rantak yang sudah populer di mana-mana, ada juga seni tari yang menggunakan properti seperti piring, payung, selendang dan sebagainya. Tari yang memakai piring disebut tari piring, tari yang memakai selendang disebut tari selendang, dan yang memakai payung disebut tari payung. Tari payung dalam prakteknya dibawakan oleh para penari berjumlah genap yang terdiri dari tiga laki-laki dan tiga perempuan.

Tari Payung bila dilihat dari sejarahnya adalah seni tari yang muncul dari daerah Agam. Menurut Sofyani (wawancara) tarian ini tercipta sebagai penggambaran cinta dan kasih sayang antara laki-laki dan perempuan. Narasi yang disampaikan merupakan simbol pergaulan muda-mudi yang bercerita tentang dirinya dan alam sekitarnya. Pemaknaan yang lebih mendalam bisa saja diarahkan pada bentuk perlindungan dan kasih sayang suami kepada istrinya dalam membina kehidupan rumah tangga agar selalu dalam kondisi damai, bahagia, dan sejahtera.
Selain payung sebagai properti, tari payung juga menggunakan selendang untuk ditarikan. Properti payung akan bermakna lain ketika dimainkan dalam sebuah tarian yang dipadukan dengan selendang sebagai pelengkap. Payung digunakan oleh penari laki-laki yang melambangkan bentuk perlindungan seorang laki-laki yang menjadi kepala rumah tangga dalam keluarga. Adapun selendang khas Minangkabau dipakai oleh penari wanita yang melambangkan ikatan cinta suci yang penuh dengan kesetiaan seorang wanita serta bentuk kesiapannya dalam membangun rumah tangga.

Menurut Zulkifli (wawancara) bahwa tari payung pernah populer sekitar tahun 1960 dan menjadi tari yang sering dipertunjukan di lingkungan masyarakat Minangkabau atau masyarakat lainnya. Masyarakat beranggapan bahwa tari payung menjadi ikon tari Minangkabau dan menjadi tontonan yang wajib dipertunjukan dalam kegiatan pesta apa saja. Tari ini seringkali ditampilkan dalam paket pertunjukan tari Minangkabau, baik dalam bentuk hiburan dan pertunjukan seni lainnya. Sering kali dibawakan pada saat pembukaan suatu acara pesta, pameran atau bentuk kegiatan lainnya.

Tari Payung pada masa lalu sering menjadi bagian dalam pertunjukan sandiwara kampuang. Sandiwara kampuang merupakan seni drama yang diperkenalkan oleh Belanda atau disebut juga dengan toonel. Selain toonel, di Minangkabau sudah ada teater tradisional yaitu randai. Ciri-ciri randai memiliki persamaan dengan ciri-ciri yang ada dalam teater rakyat yang ada di daerah Indonesia lainnya yaitu; 1) penonton tidak terikat dengan apa yang mereka tonton; 2) melibatkan beberapa aspek dan bersifat total; dan 3) pengindahan atau stilisasi (Bandem dan Murgiyanto, 2000: 13-17). Pementasan randai, penonton boleh datang terlambat dan mondar mandir meninggalkan tempat duduk tanpa membuat penonton lain menggerutu. Bahkan ada pementasan randai itu yang tidak memiliki tempat duduk untuk penonton. Penonton boleh saja duduk di mana dia suka. Penonton kadang-kadang menjadi bagian dari pementasan, karena mereka sering memberikan sambutan atau respons terhadap pementasan, baik itu berupa siulan ataupun cemoohan. Menikmati pementasan randai juga boleh sambil ngobrol dengan teman, duduk, merokok, makan kacang dan lain-lain.

Dalam perkembangan berikutnya, tari payung dimodifikasi oleh Syofyan Naan di Kayutanam. Mulai saat itu tari payung memiliki banyak varian seperti tari payung Hoerijah Adam, Sjofyani Yusaf dan Gusmiati Suid. Semuanya memiliki andil dalam menciptakan Tari Payung dengan gubahan dan kreasi mereka yang khas, meski tetap berpijak pada unsur tarian sebelumnya. Melalui ketiganya, dari abad ke-20 hingga sekarang, Tari Payung yang populer adalah karya dari Sjofyani Yusaf.

Menurut Syafrayuda (2015: 180-203) bahwa Sebagai se- 
buah tari yang terlahir pada tahun 1920-an, Tari Payung mengusung karakteristik tari Minangkabau pada masa itu yang cenderung memiliki gerak lemah lembut. Mengenai hal ini, gerakan tari diibaratkan sebagai gerak "siganjua lalai, pado suruik maju nan labiah. Alu tataruang patah tigo, samuik tapijak indak mati" (pada surut maju yang lebih, Alu tertaruang patah tiga, semut terpijak tidak mati) yang kurang lebih mewakili gerak yang lemah lembut, namun tetap mengandung ketajaman dan kekuatan.

Ditambahkan oleh Syafrayuda (2015: 180-203) bahwa mengingat dalam sejarah perkembangannya, diketahui bahwa yang populer hingga saat ini adalah Tari Payung karya Sjofyani Yusaf, maka apa yang tersaji disini lebih menggambarkan tari tersebut. Tari Payung ini cenderung serempak (unison) dibawakan oleh penari berjumlah genap yaitu enam orang. Sehingga tari yang ditampilkan terkesan lebih teratur karena semua penari menarikan tari ini dengan gerakan yang sama. Dalam hal gerakan, Tari Payung karya Sjofyani memiliki gerak yang lebih ringan dan tidak terikat oleh aturan-aturan yang rumit. Melalui gerakannya juga, tarian ini termasuk tari Minangkabau gaya Melayu, selain terdapat pengaruh tari Minangkabau juga terdapat gaya gerak tari Melayu. Gerakan tari Minangkabau bisa dilihat dalam gerak pencak silat oleh penari laki-laki, sementara gaya Melayu lebih terlihat pada gerak seperti lenggang, lenggok dan joget.

Tari payung tentu saja melibatkan perempuan sebagai penarinya, hal ini menandakan bahwa tari payung muncul ketika perempuan sudah diperbolehkan menari dan dapat dipertontonkan di depan khalayak ramai. Menurut Wisran Hadi (2006:3) bahwa perubahan yang terjadi berikutnya adalah perubahan nilai-nilai budaya yang sangat besar. Globalisasi yang melanda dunia saat ini semakin mengarah pada bentuk imperialisme budaya Barat terhadap budaya-budaya lain. Nilai-nilai budaya lokal (Minangkabau) tergusur menjadi budaya yang bebas nilai. Hal ini menyuburkan perubahan yang besar pula dalam penciptaan tari Minang. Akibatnya, tari Minang tidak dapat lagi dibedakan dengan tari yang bukan Minang. Baik pada tema, gerak, judul, harmoni dan citarasa. Bahkan pelakupelaku seni tari itu sendiri tak lagi terlihat sebagai orang Minang, tetapi adalah manusia "lain" yang kebetulan bermukim di ranah Minang.

Ditambahkan oleh Wisran Hadi (2007: 1) bahwa globalisasi merupakan konsep pemikiran tentang perlunya sebuah tatanan kehidupan masyarakat modern yang terbebas dari keterbatasan wilayah teritorial kenegaraan, wilayah geografis termasuk juga agama dan budaya, sebagai dampak terhadap ancaman perbenturan kebudayaan yang mungkin akan semakin tajam di kemudian hari. Perbenturan kebudayaan tersebut mungkin akan semakin tajam dengan semakin menguatnya etnisitas budaya dari setiap bangsa. Untuk menghindari perbenturan ini, diperlukan suatu bentuk kesatuan politik untuk kehidupan bersama.
Tatanan kehidupan bersama demikian, disebut sebagai tatanan kehidupan manusia dalam era modern yang terbebas dari segala sekatan dan keterbatasan itu tadi. Sayangnya, pemikiran yang tampaknya begitu bagus itu, dalam pengaplikasiannya bangsa-bangsa yang maju tetap berada dalam posisi yang strategis dan menentukan, sedangkan bangsa-bangsa yang masih berkembang tetap menduduki posisi sebagai pengekor dan tidak dapat menentukan apa pun.

Payung dalam Ritual Perkawinan

Upacara adat perkawinan adalah salah satu tradisi masyarakat yang masih dianggap memiliki nilai-nilai yang masih cukup relevan bagi kebutuhan masyarakat pendukungnya. Dalam upacara perkawinan, payung menjadi simbol menyatukan dua anak manusia dalam sebuah keluarga. Perkawinan yang ideal menurut adat Minangkabau adalah laki-laki yang mengawini anak perempuan mamak-nya (paman dari pihak ibu). Itu sebabnya istri mamak (bibi) dipanggil juga dengan mintuo (mertua). Kalau laki-lakinya adalah dari pihak mamak, maka laki-laki tersebut disebut mengawini anak bako.

Dalam prosesi perkawinan di Minangkabau, payung digunakan untuk melindungi mempelai baik mempelai laki-laki maupun perempuan. Payung ini juga dinamakan dengan payung kuning, walaupun warnanya tidak kuning. Cuma sebagai penanda warna kuning, maka dililitkan kain kuning di bagian atas payung. Biasanya kedua mempelai dipayungi dalam melaksanakan ritual perkawinan seperti ritual pasumandan dan manjalang. Maknanya agar dalam membangun rumah tangga mereka selalu rukun dan dilindungi oleh Allah SWT.

Dilihat dari sisi kebudayaan, payung juga bisa dimaknai sebuah rumah gadang yang melindungi anak kemenakan. Secara sosial, kelompok masyarakat yang paling kecil di Minangkabau adalah rumah tangga. Rumah tangga pada mulanya tidak bisa diartikan sebagai satu suami, satu istri dan anak dari suami istri tersebut, akan tetapi adalah sekelompok orang yang berada satu atap rumah gadang. Dalam satu rumah gadang bisa terdiri dari beberapa keluarga, tergantung dari jumlah anak perempuan yang ada dalam rumah gadang tersebut. Anak perempuan yang telah bersuami akan tetap tinggal dengan suaminya di rumah gadang milik kaum perempuan. Kalau dalam rumah gadang terdiri dari empat anak perempuan yang telah bersuami, maka jumlah keluarga yang tinggal dalam satu rumah gadang adalah empat juga, walaupun makan dan minumnya dipisahkan. Rumah gadang tidak hanya sebagai tempat tinggal suatu keluarga, tetapi juga sebagai pusat kegiatan adat pada masa dulu.

Dalam satu payung terdapat keluarga inti yang terdiri dari ayah, ibu dan anak-anak dan mereka tinggal di rumah gadang asal ibu. Masing-masing masih erat terlibat dengan keluarga asalnya. Menurut sistem matrilineal, per- 
empuan memiliki hak penuh di rumah gadang. Anak-anak perempuan yang sudah berkeluarga (kawin) tinggal pada kamar-kamar rumah gadang bersama suaminya. Anakanak perempuan yang sudah dewasa tidur di ruang tengah bersama-sama saudara perempuan mereka dari saudara ibu. Anak laki-laki yang sudah berumur tujuh tahun disuruh belajar di surau dan menginap di surau.

Kalau keluarga ini sudah berkembang banyak dan tidak muat lagi dalam satu rumah gadang, maka pihak laki-laki dari keluarga ibu atau yang disebut juga dengan mamak (paman) akan berunding dan menyepakati untuk membuat rumah gadang baru yang merupakan cabang dari rumah gadang yang sudah ada. Anak perempuan paling tua yang sudah kawin akan menempati rumah gadang baru tersebut bersama anak-anaknya. Maka akan muncul payungpayung yang lain yang saling berhubungan.

Sementara anak laki-laki yang belum kawin harus tidur di surau dan belajar tentang adat dan agama bersama temanteman dan saudara laki-laki lainnya. Kalau ada laki-laki yang tidur di rumah gadang akan diejek sebagai anak perempuan atau anak laki-laki yang masih menetek dengan ibunya. Bagi anak laki-laki hal ini sangat memalukan. Apalagi kalau di rumah gadang itu banyak saudara-saudara perempuannya, maka bisa saja teman-temannya mengejeknya dengan tuduhan bahwa laki-laki tersebut ingin mengawini saudaranya sendiri. Artinya, payung fungsinya menunjang sistem matrilineal dalam kebudayaan Minangkabau.

Kalau tidak ada pekerjaan, laki-laki akan pulang hanya untuk makan, kemudian kembali ke surau atau yang sudah lebih dewasa akan pergi ke kedai-kedai. Di kedai atau gelanggang yang lebih besar bersama-sama dengan teman-temannya akan memperagakan kepandaian masing-masing, mulai dari silat lidah sampai pada permainan olah raga. Secara fisikal seorang laki-laki yang belum berkeluarga tidak menetap di rumah ibunya, walaupun dia masih menjadi anggota keluarga ibunya. Rumah adat bagi laki-laki hanya sebagai rumah tunjuk, yaitu rumah yang ditunjuk sebagai tempat asal atau hanya untuk menyatakan identitas. Dengan demikian laki-laki tidak mempunyai rumah yang berstatus sebagai hak milik.

Pekerjaan atau aktifitas kehidupan dilakukan secara bersama-sama dalam rumah tangga yang besar dalam satu rumah gadang di bawah koordinasi mamak (saudara laki-laki dari pihak ibu) atau paman. Pada dasarnya mamak terdiri dari tiga, yaitu mamak rumah, mamak kaum, dan mamak suku. Mamak rumah adalah saudara laki-laki ibu atau garis "serumah gadang" yang berfungsi sebagai pembimbing, membina dan memelihara kemenakan-kemenakannya atau anak-anak dan anggota keluarga garis ibu terdekat. Mamak rumah sering disebut juga dengan mamak tungganai.

Ayah atau suami yang terdapat dalam satu suku disebut dengan sumando oleh mamak tungganai. Ibu dan Bapak dari istri dipanggil oleh suami dengan sebutan mintuo (mertua), begitu juga sebaliknya. Hubungan sumado dengan sumando lainnya dalam satu persukuan disebut pambayan, sedangkan hubungan kedua orang tua istri dengan kedua orang tua suami disebut dengan besan.

Seorang ayah yang baik adalah ayah yang mampu memayungi anak dan kemenakannya dengan baik, sesuai dengan pepatah berikut.

\section{Kaluak paku kacang balimbiang, Ambiak salodang lenggang-lenggangkan, Anak dipangku kamanakan dibimbiang, Urang kampuang dipatenggangkan. \\ (Keluk paku kacang belimbing, \\ Ambil selodang lenggang-lenggangkan, Anak dipangku, kemenakan dibimbing, Orang kampung dipikirkan).}

Pengertian pantun tersebut mengisyaratkan bahwa seorang laki-laki Minangkabau akan bertindak sebagai pelindung keluarga baik keluarga sendiri (anak kandung) maupun keluarga dari saudara perempuanya (kemenakan). Laki-laki juga harus bisa melindungi kampung. akan tetapi tugas terpenting dalam kebersamaan adalah tugas seorang $m a$ mak terhadap kemenakannya. Oleh sebab itu kemenakan harus patuh pada mamak-nya dan ini sesuai dengan pepatah berikut.

\section{Kamanakan barojo ka mamak, Mamak barajo ka panghulu, Panghulu barajo ka mufakat, Mufakat barajo ka nan bana. (Kemenakan beraja kepada mamak, Mamak beraja kepada penghulu, Penghulu beraja kepada mufakat, Mufakat beraja kepada yang benar).}

Kemenakan harus patuh pada mamak-nya (paman dari pihak ibu), paman ini patuh pada mamak yang lebih tinggi (penghulu suku), sedangkan penghulu suku ini juga tidak bisa sekehendak hatinya saja, harus patuh pada mufakat bersama, sementara mufakat adalah mencari kebenaran. Dalam banagari (bernegeri), laki-laki yang kawin dengan perempuan dari nagari lain akan disebut sumando nagari di nagari istrinya. Begitu juga dengan istrinya adalah sumando nagari di nagari suaminya. Di tingkat nagari, sumando perempuan maupun laki-laki memiliki peranan yang penting. Dia sangat dihargai oleh masyarakat nagari. Bahkan tempat bagi masyarakat untuk mempersembahkan rundingan dalam menghadapi masalah-masalah tertentu. Tanggung jawab individu dalam masyarakat tercermin dalam pepatah berikut.

Tagak badunsanak mamaga dunsanak, Tagak bakampuang mamaga kampuang,

Tagak basuku mamaga suku, 
Tagak banagari mamaga nagari,

Tagak babangso mamaga bangso.

(Dalam bersaudara harus melindungi saudara,

Dalam berkampung harus melindungi kampung,

Dalam bersuku harus melindungi suku,

Dalam berbangsa harus melindungi bangsa).

Arti dari mamangan tersebut adalah bahwa kalau individu manusia itu berada dalam keluarganya, maka dia wajib melindungi saudara-saudaranya. Bila individu sedang berada dalam lingkungan yang besar (kampung), maka dia wajib melindungi kampungnya. Begitu juga kalau dia sedang berada dalam suku kaumnya sendiri, maka dia akan melindungi sukunya. Lebih besar lagi kalau dia sedang menghadapi negara atau bangsa maka dia memiliki kewajiban untuk membela negara atau bangsanya sendiri.

\section{SIMPULAN}

Eksistesi payung dalam kebudayaan Minangkabau terus berkembang sesuai dengan kebutuhan umat manusia. Payung dalam pengangkatan penghulu berfungsi sebagai pelindung dari pengaruh jahat. Penghulu merupakan pemimpin bagi kaumnya dan juga masyarakat secara luas. Sebagai pemimpin, penghulu harus jauh dari sifat-sifat yang akan merugikan komunitasnya, seperti korupsi yang akhir-akhir ini sangat banyak dilakukan oleh pemimpin. Payung dalam konteks pengangkatan penghulu juga menyimbolkan bahwa seorang penghulu harus mampu memayungi akan kemenakannya.

Eksistensi payung juga berkaitan dengan eksistensi perempuan di Minangkabau. Perempuan di Minangkabau adalah sosok penting dalam sistem matrilineal. Perempuan adalah payung bagi anak-anaknya di rumah gadang. Rumah gadang juga payung bagi seluruh penghuninya, dimana perempaun sebagai tonggaknya. Maka dalam mamangan adat dikatakan bahwa perempuan di Minangkabau adalah payung panji ke Medinah yang artinya perempuan akan membawa seluruh penghuni rumah gadang menuju jalan yang baik.

Eksistensi payung di Minangkabau juga dikaitkan dengan kesenian. Ada tari payung di Minangkabau yang menggambarkan tentang kebahagiaan umat manusia dalam berumah tangga. Tari payung juga menggambarkan tentang hubungan percintaan anak muda yang belum berumah tangga. Tarian ini dilakukan oleh tiga penari laki-laki dan tiga penari perempuan yang menyimbolkan tentang manusia yang hidup berpasang-pasangan.

Eksistensi payung di Minangkabau juga ada dalam upacara perkawinan. Payung dalam upacara perkawinan dimaknai sebagai rumah tangga yang keil dan bahagia. Payung juga menjadi pelindung bagi keluarga kecil mereka nantinya. Panas dan hujan merupakan gangguan yang perlu disikapi untuk menciptakan kebahagiaan. Artinya payung adalah cita-cita dua insan manusia dalam mengarungi rumah tangga.

\section{DAFTAR RUJUKAN}

Bandem, I Made dan Sal Murgiyanto, (2000), Teater Daerah Indonesia, Yogyakarta: Pustaka Budaya dan Kanisius.

Ghazali, Adeng Muchtar, (2011), Antropologi Agama (Upaya Memahami Keragaman Kepercayaan, keyakinan dan Agama). Bandung: Alfabeta.

Hadi, Wisran, (2006), "Dunia Hiburan Tanpa Perempuan". Makalah untuk Diskusi Seni dalam kegiatan Contemporary Dance Festival (MCDF) dan acara HUT Kota Padang Panjang ke 216, Dies Natalis STSI ke 40 dan Mengenang wafatnya Hoeriyah Adam ke 35, 12 Desember 2006. Padangpanjang: STSI Padang Panjang

Hadi, Wisran, (2007), "Menyikapi Era Globalisasi”. Makalah untuk Seminar Budaya Melayu STSI Padang Panjang, 27 Januari 2007. Padangpanjang: STSI Padang Panjang

Haviland, William A. 1988. Antropologi. Jilid I dan II. Terj. R.G. Sukardjito. Jakarta: Erlangga.

Horton, Paul B. \& Chester L.Hunt, (1987), Sosiologi, Jakarta: Erlangga

Keesing, M. Roger, (1992), Antropologi Budaya: Suatu Perspektif Kontemporer, Jakarta: Erlangga

Koentjaraningrat. 1985. Pengantar Ilmu Antropologi. Jakarta : Aksara Baru.

Mariyah, Emiliana. 2011. "Kajian Budaya Universitas Udayana: Pemikiran Emansipatoris Prof. Dr. I Gusti Ngurah Bagus". Dalam Jelajah Kajian Budaya. Ed. I Made Suastika, I Nyoman Kutha Ratna, dan I Gede Mudana. Bali: Pustaka Larasan bekerja sama dengan Program Studi Magister dan Doktor Kajian Budaya Universitas Udayana.

Marzuki. (2015). Pendidikan Karakter Islam. Jakarta:Amzah

Ratna, Nyoman Kutha. 2010. Metodologi Penelitian Kajian Budaya dan Ilmu Sosial Humaniora pada Umumnya. Yogyakarta: Pustaka Pelajar.

Sanderson, Stephen K. 1993. Sosiologi Makro. Sebuah Pendekatan terhadap Realitas Sosial. Edisi kedua. (Farid Wajidi, S. Menno, Pentj). Jakarta: Rajawali Pers. 
Syafrayuda, Diah Rosari, (2015), "Eksistensi Tari Payung Sebagai Tari Melayu Minangkabau di Sumatera Barat". Jurnal Ekspresi Seni. ISSN 1412 - 1662 Volume 17, Nomor 2, November 2015. Padangpanjang: ISI Padangpanjang

Thaib, Raudha, (2008), "Perjuangan Siti Manggopoh Sebagai Spirit Perjuangan Nan Kokoh Bagi Perempuan Minangkabau", Makalah, Lubuk Basung: Seminar Pendidikan 1 Juni 2008.

Thaib, Raudha, (2010). “Perempuan Minangkabau Dulu, Kini dan Akan Datang (Perempuan dalam Perspektif Sejarah)", Makalah, Padang: Seminar KAMMI 29 Mei 2010 